\title{
How Can We Do it Right? Ethical Uncertainty in Swedish Sami Research
}

\author{
Anna-Lill Drugge ${ }^{1}$ (D)
}

Published online: 12 August 2016

(C) The Author(s) 2016. This article is published with open access at Springerlink.com

\begin{abstract}
Research related to indigenous peoples in Sweden and elsewhere has a history marked by discriminatory practice and unequal research processes. Sweden has still not been very visible in terms of openly debating, developing and implementing ethical strategies specifically suited for indigenous research. The present study explores how research ethics is discussed among scholars within the Sami research field in contemporary Sweden. Fifty-six research proposals deriving from eight different research institutions and 160 individual researchers are analyzed, discovering how scholars relate to research ethics when planning for new research projects related to the indigenous Sami. The results demonstrate that ethical guidelines for research are often referred to, but that a common view on what guidelines to use is lacking, leading to a notable variety between different researchers. Ethical discussions are present in the vast majority of the proposals, however there are notable differences between the theories around how to proceed in a culturally safe, ethical manner, and the proposed methods that are to be used to implement theory in practice. In conclusion, there exists a great uncertainty among scholars on where to seek ethical guidance, how to relate to current legislation around research ethics and at the same time act ethically in a culturally appropriate manner. This uncertainty leads to questioning whether discussions of ethics are relevant in the first place, what they are supposed to include, how they are meant to be undertaken and what consequences can be expected from the presence or absence of ethics in indigenous research.
\end{abstract}

Keywords Sami research $\cdot$ Research ethics $\cdot$ Indigenous $\cdot$ Ethical guidelines

\section{Introduction}

When formulating their research plans and putting them into practice, contemporary scholars working in sensitive fields have an ever-increasing range of alternatives to turn to for ethical

Anna-Lill Drugge

anna-lill.drugge@umu.se

1 Vaartoe/Centre for Sami Research, 90187 Umeå, Sweden 
guidance (Eriksson et al. 2008). This surely represents progress in a complex area and is to be welcomed, but a number of deep-rooted problems remain to be addressed. In Sweden debates concerning historical and current exploitative and discriminatory practices in relation to the Sami people are very much alive and ongoing; indeed, they have gained increased attention among scholars, artists, politicians and others during the past decade. The Equality Ombudsman has initiated a number of projects to map and combat discrimination against the Sami people (Pikkarainen 2008; The Equality Ombudsman 2013), and films, exhibitions and research workshops highlighting the sometimes dark and painful history of research into race biology among the Sami have also emerged; the Swedish churches have also begun scrutinizing their colonial responsibilities (Hagerman and Gabrielson 2014; Lindmark and Sundström 2016). In line with these developments, Sami political representatives continue to press for past injustices to be addressed and for recognition of an enduring colonial present. The establishment of a truth and reconciliation commission has been suggested as one way forward, an issue originally raised by the Sámi youth organization Sáminuorra (Rydenfalk 2014; Sametinget 2015; Sametinget 2016).

Perhaps inevitably in this turbulent climate, certain traditions within Sami research are being strongly challenged, and there have been calls for a greater awareness of the discriminatory, racist and unequal research processes at work in Swedish academic structures in an historical and contemporary context (Drugge 2016a, b; Ledman [Drugge] 2015; Svalastog 2013). With this troubled backdrop, developing strategies for research that can be considered as legitimate and ethical from a Sami perspective is essential for dealing with the past through an ethically sustainable present.

The purpose of the present study is to explore how research ethics is discussed among scholars within the Sami research field in contemporary Sweden. The ultimate aim of the article is to contribute positively to the development of robust and ethically sound research strategies in this field. A brief historical contextualization outlining the position of the Sami in Sweden, followed by a fairly detailed description of the development of research ethics both generally and more recently in Sweden serves as a starting point for investigating why ethics are being discussed within current Sami research in the first place, and considering why indigenous perspectives are a challenge to mainstream academic discourses. I consider contemporary practices and the discourses of ethics in Sami research by analysing fifty-six research proposals with a specific Sami focus that were submitted to one of Sweden's largest research councils in 2012. The proposals are examined through content analysis, and two basic (yet inherently complex) research questions frame the investigation. The first question explores what contemporary researchers consider relevant in relation to research ethics: specifically, what ethical guidelines are referred to, and what discourses are thus made visible? The second question concerns how theory and intended practice connect in the various research applications, and asks how questions about ethics in Sami research can be related to issues of power in the past and the present. Lastly, I discuss the potential consequences of the current structures and discourses surrounding ethics in Sami research remaining unchanged, and tentatively suggest a few ways of breaking the apparent impasse.

\section{The Indigenous Sami in Sweden}

The Sami in Sweden have been legally acknowledged as an indigenous people by the Swedish Parliament since 1977. Historical research has repeatedly shown that a process of territorial 
colonization of Sami lands by Sweden was initiated in the late seventeenth century, and Swedish dominance followed in the political, economic and cultural spheres. The process can be said to have culminated in the late nineteenth century, when the state introduced a policy directed towards the Sami as a group which fully legitimized colonial discourses and created major divisions between different groups of Sami as well as between Sami and Swedes (Brännlund 2015; Lantto 2000; Lundmark 1998; Mörkenstam 1999). Today, the Sami population in Sweden is estimated at 17,000-20,000 individuals, but given the fact that Sweden does not allow the recording of ethnic data in the censuses the accuracy of this number is uncertain and the true figure is likely to be much higher (Hassler 2005).

\section{Modern Research Ethics}

Even though discussions about research ethics continually take place in various national organizations and at many levels on a global scale, there exists no international ethics system which has won worldwide approval; instead, ethical guidelines and legislation for research have varied at different times, and continue to vary between different countries (Hunter 2014).

Within health research, ethical issues have frequently been - and still are - discussed and debated as a natural point of departure in the quest to protect the integrity and health of patients and research subjects. For this reason, a number of international agreements, such as the Nürnberg Codex, the Declaration of Helsinki and the Belmonte Report, have been formulated, particularly during the second half of the twentieth century (Milmaniene 2009; The Belmont Report 1979; The Nürnberg codex 1949; The Declaration of Helsinki 1964). In sharp contrast to the medical sphere, the importance of appropriate research ethics has not always been as apparent in the Social Sciences and Humanities: this may be because it is difficult to see the practical consequences of research when the human body itself is not exposed to physical experiments (Kalman and Lövgren 2012). A relative lack of interest in ethics has certainly been the case in research related to the issues of indigenous peoples in a Nordic context, although in recent years this has begun to change: scholars have started to take international developments into account, not least by discovering and using the works of Linda Tuhiwai Smith, Taiaike Alfred, Norman Denzin, Bagele Chilisa and other researchers working within the arena of indigenous research methodologies (Alfred and Corntassel 2005; Chilisa 2011; Denzin and Lincoln 2005; Ledman [Drugge] 2012a; Drugge 2016b; Sehlin Macneil 2014; Smith 1999). The elaboration and implementation of ethical guidelines for research has been developed as being not only a way to identify risks, but also as a means to create positive outcomes in which key issues such as justice and reciprocity are fundamental (Hudson et al. 2010).

\section{Recent Developments in Research Ethics in Sweden}

Up until 2004 there was no law regulating the ethical vetting of research in Sweden. Research councils and various faculties at different universities had established their own ethical policies, but there were no official ethical boards, and researchers were not particularly encouraged to engage with the ethical issues related to their work (Nygren 2012).

In 1997 the Swedish government decided to investigate the need for more detailed ethical guidelines for research, a move prompted by developments within academia that were 
encouraging a more explicit relationship between research and society. By establishing general guidelines that would be enshrined in law, the ambition was to create a more standardized assessment, which was seen as positive for both researchers and "the society at large" (Etikprövning av. forskning, Prop 2002/03:50 [Ethical vetting in research, Government Bill]). At the culmination of these investigations, and with the aim of establishing and increasing the confidence among citizens that research was fair, thorough and trustworthy, the Swedish Ethical Review Act came into force on January 1, 2004. Since then the Act has played an important role as researchers are obliged to follow it when planning, implementing and monitoring research projects dealing with sensitive personal information (Lag om etikprövning av. forskning som avser människor 2003:460 [Ethical Review Act]).

Even though the Act of 2004 was meant to cover all research regardless of subject area or discipline, it was clearly focused on medical research. And in fact in practice, much research within the Social Sciences or Humanities fell outside the requirements for ethical vetting since the formulations in the Act took their points of departure from predominately medical and/or quantitative research. These disparities quickly became apparent, and consequently in 2008 the Act was revised and sharpened, leading to greater demands for ethical focus within the Humanities and Social Sciences (Nygren 2012). For instance, the informed consent given to an individual researcher by the research subject was no longer considered sufficient. The Act also stated that all projects handling sensitive personal data had to undergo vetting before one of the six regional ethical boards that had been established (Nygren 2012; Personuppgiftslagen 1998:204 [Personal Data Act] 1998:20). "Sensitive personal data" in this context meant data consisting of information as to the racial or ethnic origin of the research subject, their political opinions, religious beliefs, membership of a trade union or information concerning their sexual orientation or health (Personuppgiftslagen 1998:204 [Personal Data Act]).

The regional ethical boards examine a variety of research projects and decide whether or not they comply with the Ethical Review Act. Every board consists of two departments, one being specifically responsible for medical research and the other for research which falls outside this purview, for example, work in the Humanities and Social Sciences. The Act states that every department shall consist of a chairperson (a serving or previous judge) and fifteen delegates. Ten of these fifteen shall possess academic qualifications, and the five remaining delegates shall "represent public interests" (Lag om etikprövning av. forskning som avser människor 2003:460, p. 5 [Ethical Review Act]).

\section{The Ethics of Sami Research}

Although as mentioned above interest in the specific ethics of Sami research has been awoken in Sweden (Bockgård and Tunón 2010; Jonsson 2010; Ledman [Drugge] 2007, 2012b), progress has remained slow. In fact, compared to many other countries where indigenous peoples are present, Sweden has still not been very visible in terms of openly debating, developing and implementing ethical strategies specifically suited for indigenous research; rather, discussions on Sami research ethics have usually been positioned within the more general ethical framework that was sketched in the previous section. The subject remains in its infancy, and there are still widespread uncertainties about what actually constitutes indigenous research ethics, how they can be implemented, and why (or indeed even if) such ethics actually contribute to the scientific process. 
In Sweden, this largely neglected issue has become more important than ever because the volume of research related to the Sami people has grown significantly over past twenty years or so. A large number of research projects in the field are ongoing and more are planned; the laudable ambition is to fill some of the many knowledge gaps that exist among decisionmakers, politicians, scientists and others who deal with issues involving Sami interests and needs (Axelsson and Sköld 2006). As has been explained, the 2004 Ethical Review Act has been an important piece of legislation in framing research, but crucially the Act does not contain any specific guidelines for structuring research related to Sami issues (Lag om etikprövning av. forskning som avser människor, 2004 [Ethical Review Act]; Ledman [Drugge] 2012b; Drugge 2016a). This omission is particularly striking when viewed in a global context: the lack of indigenous perspectives in Swedish research policy contrasts sharply with the situation elsewhere. For instance, in Canada, Australia, New Zealand and the United States, ethical guidelines partly based on indigenous perspectives have been formulated at different levels; all researchers are obliged to consider these perspectives when designing and conducting research that involves indigenous peoples. These guidelines have been carefully formulated around the concerns of the indigenous peoples themselves, and the assumption is that certain values are considered to be general among many indigenous groups within the same country (NESH 2002; Hudson et al. 2010; Tri-Council Policy Statement 2010: Ethical Conduct for Research Involving Humans 2010; GERAIS 2012). This cannot be considered the final word on the matter because naturally, and as noted by Johnsson et al. (2014), ethical guidelines cannot automatically guarantee ethical behaviour on the part of researchers; they do, however, usually encourage reflection and thoughtfulness.

At the moment Sweden is still severely lacking research both on ethical standards for work in this particularly sensitive field and to underpin the broader development of policy for up-todate general ethical guidelines. This problem has at least been officially recognized for some time but practical action has been slow to take effect. In order to systematically review previous Sami research, the Swedish government commissioned the Swedish Research Council Formas to provide a report on the matter more then ten years ago. The Council's survey was completed and its report published in 2006; it indicated that there was a wide range of areas of relevance to Sami society that had not yet been investigated. This was highlighted as a particular problem in relation to the vast number of state investigations that had been carried out in order to form the basis for legislative changes; many of these investigations were completed without having had access to any research-based knowledge. The Formas report recommended approaching Sami issues from a deeper and more profound scientific perspective (Hållbar rennäring och övrig samerelaterad forskning: Kunskapsöversikt 2006[Sustainable reindeer herding industry and other Sami related research]). In addition, the report also stressed the need for research to be firmly anchored in Sami society, and urged that the inclusion of Sami perspectives in research processes should be increased and valued within academia. In conclusion, the report highlighted the fact that research related to the Sami should ultimately seek to help solve contemporary problems; research results also needed to be more efficiently disseminated within Sami society itself (Hållbar rennäring och övrig samerelaterad forskning: Kunskapsöversikt 2006 [Sustainable reindeer herding industry and other Sami related research).

As a result of the 2006 Formas report, the government decided that an interdisciplinary research programme on Sami issues should be established by the three major Swedish research councils - Formas, the Swedish Research Council (VR) and FAS (Swedish Research Council for Health, Working Life and Welfare). Research funding was made available to both 
individual research projects and strong research environments that focused on "(...) the indigenous Sámi people, Sámi-related activities, health, working and living conditions.” The programme was finally launched in 2012 and was opened to researchers from all scientific disciplines in the hope of encouraging interdisciplinary approaches. By the end of the application period, fifty-six applications from a range of individual researchers, universities and research institutions had been registered. These were later evaluated and ranked by an international panel, and in the end a total of ten research projects were granted funding.

\section{Source Material, Study Design and Methods}

The fifty-six proposals that form the source material for the present study derive from eight different Swedish research institutions. Every proposal had a main applicant (forty-nine unique applicants) and 124 co-applicants (111 unique co-applicants, myself included), and thus in sum, 160 individual researchers were involved in applying for funding. The indigenous research field in Sweden is rather small, and it is likely that this number represents the vast majority of the researcher collective in Sweden currently engaged in (or likely to be involved in) Sami research. Therefore, the source material constitutes a trustworthy representation of contemporary Swedish Sami research, and provides a valuable insight into how ethical discussions are present - or absent - within scientific circles.

It is clear that the majority of Sami research in Sweden is centred around four research institutions: twenty-three of the applications were based at Umeå University (41 \%), eleven at Uppsala University (20\%), nine at the Swedish University of Agricultural Sciences (16\%) and eight at Stockholm University (14\%). ${ }^{1}$ The names of several researchers $(29 \%)$ occur in more than one submission, either as the main or co-applicants, and it is apparent that collaboration between researchers from different departments and disciplines is frequent. Both researchers with long experience of working within the Sami research area, and researchers with no or little experience of the field can be found among the applicants. There are relatively few Sami academics in Sweden and initiatives towards Sami-centred research or suggestions that indigenous ideas about knowledge and investigations might frame design, analysis or dissemination are scarce. For this reason, it is not surprising that the vast majority of the proposals are written from a predominately mainstream, Swedish perspective.

The source material was collected, categorized and analysed by using a qualitative content analysis approach as described by Hsieh and Shannon (2005). They define qualitative content analysis through three distinct approaches: the conventional, when codes are defined during data analysis and derive from the data itself; the directed, when codes are defined before and during the analysis and stem from theory and research findings; and the summative, when keywords are selected before and during data analysis and derive from the researchers' own interests or relevant literature (p. 1286). In the present study, a combination of the conventional and directed content analytical methods has been used. A conventional approach was used when dealing with the question of what was emphasized as ethically important. The categories were in this case identified during the analysis and derived from the content of the source material. In the part of the study that demonstrates the presence and naming of ethical

\footnotetext{
${ }^{1}$ The remaining proposals (one for each of the following institutions) are based at Luleå University of Technology, University of Gothenburg, the Nordic Museum, the University West, and finally the Mid-Sweden University.
} 
guidelines, a directed content analytical approach was used. I searched specifically for sections where ethical guidelines with different names were referred to in the texts, adding new codes (guidelines) as they emerged.

All of the proposals were analysed in their entirety. By examining the textual content of the applications it was possible to extract all sections that in one way or another were related to research ethics or ethical considerations of any kind. Although the applications included the standard heading "Ethical considerations", it is clear that ethical discussions were not always placed exclusively under that head, and some were included in other parts of the applications. The results are presented by quantitative data as well as by quotes extracted directly from the sources. The quotes have been selected to underscore and highlight the quantitative information. It should be noted that even though the standard heading "Ethical considerations" was a mandatory section in the applications, this does not automatically mean that researchers express their opinions or strategies in relation or reveal accurate portrayals of what they "really" think. In Sweden, funding is generally granted before any ethical assessment of the ethical implications of the research project. Given that fact, researchers are not necessarily obliged to reflect on ethical implications before funding is granted, and what they write about research ethics does not automatically correlate to how ethical issues will be handled during the research process.

\section{Results}

\section{Projects which Refer to Ethical Guidelines}

In line with a directed content analytical approach (Hsieh and Shannon 2005, p. 1281), targeted questions about the category "ethical guidelines" were asked. In twenty-four (43\%) of the applications, references to ethical guidelines, legislative Acts or protocols are wholly absent and therefore not discussed at all. As for the remaining thirty-two $(57 \%)$ proposals, ethical considerations are most frequently manifested by referring to either the CODEX (rules and guidelines for research) of the VR (Swedish Research Council), to the regional ethical review boards or to the national Ethical Review Act. In ten of these cases two or more ethical guidelines are referred to in combination. In six of the proposals the issue of research ethics is present, but in a rather subtle and indefinite manner, as in, for instance, expressions such as "generally accepted ethical values" or "Guidelines for social sciences researchers". Four of the applications include references to and/or discussions on international ethical guidelines for indigenous research. These guidelines are, however, different from each other and have their origin in several indigenous and national contexts.

The results clearly demonstrate that there is a divergence among Swedish scholars when it comes to what ethical guidelines or principles to refer to in relation to Sami research projects. This indicates uncertainty that can be related to what Johnsson et al. have pointed out: there is an increasing number of ethical guidelines to consider in a Swedish scientific context, but at the same time there is a lack of clear guidance on how they relate to each other, leading to the fact that "many researchers struggle with inconsistent sets of norms" (Johnsson et al. 2014, pp. 39-40). In addition, in the present study at least, individual researchers demonstrate varying approaches to ethics, which indicates that scholars are rather inconsistent in their views on what discussions around research ethics should include. And it should perhaps be reiterated at 
this point that of the ten proposals that were granted funding only six of them made reference to ethical guidelines.

It is clear from the foregoing that there exists great uncertainty among researchers when it comes to defining what research ethics is about and how to approach it in specific research projects. Three different approaches are identified. The first approach appears to be to ignore the issue: no less than $43 \%$ of the proposals do not refer to any ethical guidelines or protocols. Of course this does not automatically mean that discussions of an ethical character are absent, but it does show that these researchers do not necessarily link available ethical guidelines to their own research. A second approach is typified by the group of researchers that seek to follow national ethical standards and legislation governing research ethics (see Table 1). These researchers are likely to meet the existing requirements and can position themselves within the established system, thereby running a limited risk of being considered unethical from a legislative and/or academic point of view. It is a legitimate and safe position, but one that does not necessarily correlate to what is considered to be ethical from the point of view of indigenous peoples. The third approach is in some ways the most interesting; the group that embodies this approach looks in a different direction, acknowledging an international and more culturally sensitive understanding of research ethics by encouraging discussions that take indigenous perspectives into account. However, adopting this somewhat broader interpretation of research ethics does not imply that there is consensus in how this should be done or what ethical guidelines should be followed. Indeed, connecting theory to practice appears to be a struggle for those who are willing to accept a broader definition of research ethics. In this respect, it cannot be overlooked that Swedish academia does not provide the individual scholar with any clear and helpful instruments for how to accomplish indigenous research that is ethically sustainable. When applying ethical guidelines to research processes Eriksson et al. argue that "there will always be a gap between the rules and the practice they are meant to regulate". Interpretation shifts between individuals, which inevitably means that ethical behaviour depends on the perspectives and ethical foundations of the specific researcher (Eriksson et al. 2008, p. 16). In line with this reasoning, the results here demonstrate a notable glitch between the theories around how to proceed in a culturally safe, ethical manner, and the proposed methods that are to be used to implement theory in practice. International discourses around ethical guidelines for indigenous research are identified as an inspiration to some scholars within the field, but these guidelines are seldom adjusted to Sápmi (Sami land) or to the specificities of Sami society; as a consequence, implementing the guidelines in a practical way while conducting Sami research at Nordic, national, regional and local levels will always be difficult without making significant adjustments or local adaptations. "Trying to do things right" by making use of ethical guidelines for research is an honourable but evidently complicated approach that is readily discussed in theory, but more difficult to apply in practice.

\section{Discussing Research Ethics}

Apart from references to specific ethical guidelines in the source material, discussions on research ethics can also be found in the running texts of the applications, and all fifty-six proposals contain some discussion of ethics. By departing from a conventional analytical 
Table 1 Proposals (thirty-two of fifty-six) for research funding addressed to Formas, and referring to ethical guidelines for research

\begin{tabular}{|c|c|c|c|c|c|c|c|}
\hline$N=32$ & Codex & EPN/EPL & Helsinki & PUL & Indigenous & $\mathrm{CBD}$ & Undefined \\
\hline 1 & $\mathrm{X}$ & & & & & & \\
\hline 2 & & $X$ & & & & & $X$ \\
\hline 3 & $X$ & & & & & & \\
\hline 4 & $\mathrm{X}$ & & & & & & \\
\hline 5 & & $\mathrm{X}$ & & & & & \\
\hline 6 & $\mathrm{X}$ & & & & & & \\
\hline 7 & $\mathrm{X}$ & & & & & & \\
\hline 8 & $\mathrm{X}$ & & & & & & \\
\hline $9^{*}$ & & $\mathrm{X}$ & & $\mathrm{X}$ & & & \\
\hline 10 & $\mathrm{X}$ & & & & & & \\
\hline 11 & & & & $\mathrm{X}$ & & & \\
\hline 12 & & & & & $\mathrm{X}$ & $X$ & \\
\hline 13 & & & & & & & $X$ \\
\hline 14 & & $\mathrm{X}$ & & & & & $\mathrm{X}$ \\
\hline $15^{*}$ & $\mathrm{X}$ & $\mathrm{X}$ & & & & & \\
\hline $16^{*}$ & & $\mathrm{X}$ & $\mathrm{X}$ & & & & \\
\hline $17 *$ & $\mathrm{X}$ & & & & & & \\
\hline $18 *$ & & & & & $\mathrm{X}$ & & \\
\hline 19 & $\mathrm{X}$ & $\mathrm{X}$ & & & & & \\
\hline 20 & & $\mathrm{X}$ & & & & & \\
\hline 21 & & & & & $X$ & & \\
\hline 22 & & $\mathrm{X}$ & & & & & $\mathrm{X}$ \\
\hline 23 & & $\mathrm{X}$ & & & & & \\
\hline 24 & & & & $\mathrm{X}$ & & & \\
\hline 25 & & & & & & & $\mathrm{X}$ \\
\hline 26 & $\mathrm{X}$ & & & & & & \\
\hline 27 & & $\mathrm{X}$ & & & & & \\
\hline 28 & & $\mathrm{X}$ & & & & & \\
\hline 29 & & & & & $\mathrm{X}$ & & \\
\hline 30 & & $\mathrm{X}$ & & $\mathrm{X}$ & & & \\
\hline $31 *$ & $\mathrm{X}$ & $\mathrm{X}$ & & & & & $\mathrm{X}$ \\
\hline 32 & $\mathrm{X}$ & $\mathrm{X}$ & & & & & \\
\hline Total & 13 & 15 & 1 & 4 & 4 & 1 & 6 \\
\hline$\%$ & 40 & 47 & 3 & 13 & 13 & 3 & 19 \\
\hline
\end{tabular}

Source: Fifty-six proposals submitted in response to the call for "Support studies of the indigenous Sami people, Sámi-related activities, health, working and living conditions", Formas 2012. Projects granted funding marked by *

perspective, a number of categories were identified in the source material and organized into clusters. In this part of the study, and once again following the definition of Hsieh and Shannon, the categories derive from the content of the texts and were not, in contrast to the first part of the study, predefined before approaching the content of the proposals (Hsieh and Shannon 2005, p. 1279). What is emphasized as important differs between the submissions, and four separate categories stand out: collaboration, dissemination, informed consent and anonymity. In 
Table 2 Discussing research ethics: the four categories

\begin{tabular}{|c|c|c|c|c|}
\hline $\mathrm{N}$ & Collaboration & Dissemination & Informed consent & Anonymity \\
\hline 1 & & & $\mathrm{X}$ & \\
\hline 2 & & & $\mathrm{X}$ & \\
\hline 3 & $X$ & $\mathrm{X}$ & $\mathrm{X}$ & $\mathrm{X}$ \\
\hline 4 & $\mathrm{X}$ & & & \\
\hline 5 & $\mathrm{X}$ & $\mathrm{X}$ & & \\
\hline 6 & & & $\mathrm{X}$ & \\
\hline 7 & $\mathrm{X}$ & & $\mathrm{X}$ & $\mathrm{X}$ \\
\hline 8 & $X$ & & $\mathrm{X}$ & $\mathrm{X}$ \\
\hline 9 & $X$ & $X$ & $\mathrm{X}$ & \\
\hline 10 & $\mathrm{X}$ & $\mathrm{X}$ & $\mathrm{X}$ & \\
\hline 11 & $\mathrm{X}$ & & & \\
\hline 12 & $\mathrm{X}$ & $\mathrm{X}$ & & \\
\hline 13 & & $\mathrm{X}$ & & \\
\hline 14 & $X$ & & & \\
\hline 15 & & & $\mathrm{X}$ & $\mathrm{X}$ \\
\hline 16 & $\mathrm{X}$ & $\mathrm{X}$ & $\mathrm{X}$ & $\mathrm{X}$ \\
\hline $17 *$ & $\mathrm{X}$ & $\mathrm{X}$ & $\mathrm{X}$ & \\
\hline $18 *$ & & & & $\mathrm{X}$ \\
\hline 19 & $X$ & $\mathrm{X}$ & $X$ & $\mathrm{X}$ \\
\hline 20 & $\mathrm{X}$ & $\mathrm{X}$ & $\mathrm{X}$ & \\
\hline 21 & & $\mathrm{X}$ & & \\
\hline 22 & $\mathrm{X}$ & & & \\
\hline 23 & $\mathrm{X}$ & $\mathrm{X}$ & $X$ & \\
\hline $24 *$ & $X$ & $\mathrm{X}$ & & \\
\hline $25^{*}$ & $\mathrm{X}$ & & & \\
\hline 26 & $\mathrm{X}$ & & & \\
\hline 27 & & & $\mathrm{X}$ & \\
\hline 28 & $\mathrm{X}$ & $\mathrm{X}$ & & \\
\hline $29 *$ & $\mathrm{X}$ & $\mathrm{X}$ & & $\mathrm{X}$ \\
\hline 30 & $\mathrm{X}$ & & & \\
\hline 31 & & & $\mathrm{X}$ & $\mathrm{X}$ \\
\hline 32 & $X$ & $X$ & & $X$ \\
\hline $33 *$ & $X$ & $X$ & & \\
\hline 34 & & $X$ & $\mathrm{X}$ & \\
\hline 35 & & & $X$ & \\
\hline $36^{*}$ & $X$ & $X$ & $X$ & $X$ \\
\hline 37 & $X$ & & & \\
\hline $38 *$ & $X$ & $X$ & & \\
\hline $39 *$ & $X$ & & & \\
\hline 40 & $X$ & $X$ & $X$ & \\
\hline 41 & $X$ & $X$ & & \\
\hline 42 & $X$ & & & \\
\hline 43 & $X$ & $X$ & & \\
\hline 44 & & $X$ & & \\
\hline
\end{tabular}


Table 2 (continued)

\begin{tabular}{lllll}
\hline $\mathrm{N}$ & Collaboration & Dissemination & Informed consent & Anonymity \\
\hline 45 & $\mathrm{X}$ & $\mathrm{X}$ & & \\
46 & $\mathrm{X}$ & $\mathrm{X}$ & & $\mathrm{X}$ \\
47 & $\mathrm{X}$ & $\mathrm{X}$ & $\mathrm{X}$ & $\mathrm{X}$ \\
48 & & & $\mathrm{X}$ \\
49 & $\mathrm{X}$ & $\mathrm{X}$ & & $\mathrm{X}$ \\
50 & $\mathrm{X}$ & $\mathrm{X}$ & & $\mathrm{X}$ \\
51 & $\mathrm{X}$ & $\mathrm{X}$ & & \\
52 & $\mathrm{X}$ & $\mathrm{X}$ & & \\
53 & $\mathrm{X}$ & $\mathrm{X}$ & $\mathrm{X}$ & \\
$54 *$ & $\mathrm{X}$ & $\mathrm{X}$ & & 29 \\
55 & & $\mathrm{X}$ & 22 & \\
56 & & 34 & 39 & \\
Total & 41 & 61 & & \\
$\%$ & 73 & & & \\
\hline
\end{tabular}

Source: Fifty-six proposals submitted in response to the call for "Support studies of the indigenous Sami people, Sámi-related activities, health, working and living conditions", Formas 2012. Projects granted funding (10) marked by *

the ten proposals that were granted funding, nine highlighted collaboration as important, seven discussed the issue of dissemination, three underlined anonymity and two the question concerning informed consent (see Table 2). These categories are now considered in turn.

\section{Collaboration}

In forty-one of the applications (73\%), the importance of collaboration or cooperation with different Sami actors, organizations or institutions is prominently expressed in the running text. The Sami Parliament is given an important role as a possible collaborative partner in the research process in some cases (12\%), as is the National Sami Association (SSR) (7\%). However, it is important to remember that the Sami Parliament itself has not officially promulgated any research policy or ethical guidelines for researchers to consider. At the same time, it certainly lies within the discourse that the Sami Parliament should be seen as a natural party to consult during research processes (Svalastog 2013, p. 18).

Some Sami individuals appear in the applications as named, and various Sami institutions are mentioned in terms of possible partners. Collaboration is described in terms of creating Sami reference groups, or engaging Sami reference persons within and/or outside academia. In addition, other scholars within the research area are also occasionally mentioned as possible reference persons. The role of these proposed reference groups or persons varies; in some cases, Sami participants are described as actors that are offered influence and participation from the start of the project:

"Representatives from these organizations will be part of the research project from the beginning and involved in everything from designing questionnaires to interpreting results. A reference group will be established and regular meetings held during the full time of the project." 
In other cases, Sami reference persons or groups are presented as having the role of experts whose knowledge could be of benefit to the project, but without clear involvement or the possibility of influencing the research process as such:

"We will put together a reference group with representatives from the National Union of the Swedish Sami People (SSR), the Sami Parliament, The Swedish Environmental Protection Agency, and the County Administration Boards. This reference group will meet with the researchers at least once every year."

It is clear that researchers in general are positive about engaging reference persons or groups to be a part of the research process. However, how collaboration is supposed to be accomplished, who will control it and what strategies and methods are to be used in order to carry through collaborative processes all vary in both definition and description.

The results of the present study indicate that the concept of collaboration is focused around issues such as transparency and information-sharing directed from the academy to the Sami community; the latter is given the opportunity to react, but is not necessarily accorded the power to influence the knowledge production process, which remains firmly in the hands of the researchers:

"We will form a reference group including herders and representatives from Sámi organisations and management agencies. Reindeer herders in our study areas willfully participate in the project through discussions and practical work in the field. This collaboration will ensure that the reindeer herders experience and perspectives are taken into consideration and form the basis for our scientific work."

In a general academic context in Sweden (and internationally), collaborative processes have primarily been focused on economic and technological development rather than human and societal values (Ett lyft för forskning och innovation, proposition 2008/09:50 [An improvement for research and innovation. Government Bill]. Knowledge production has a history of being understood as a task for the scientific community alone to accomplish, but this is an opinion that is being increasingly contested within the field of indigenous research. Instead, the involvement of knowledge users as equal partners in the scientific process is encouraged, the aim being to produce knowledge that is relevant and useful to both community and academy (CIHR 2012). Critical voices have, however, pointed out that the drive to establish equal partnerships in research processes needs to be handled carefully in order to avoid the risk of handing over responsibility for the research project to someone other than the researcher, who might then be held accountable for any errors that are found (Brännlund 2015). Furthermore, it has also been noted that collaboration through culturally careful strategies is something that researchers often strive to accomplish, but even with the best of intentions many cultural missteps are made along the way (Schinke et al. 2010).

\section{Dissemination}

The second most frequently mentioned theme in terms of the ways in which the subject of research ethics is addressed relates to the issue of disseminating research results (see Table 2). Communicating research results is frequently underscored as one of the main goals; however, to whom and how these results are to be communicated differs. Most commonly, dissemination of the results is discussed in terms of popular publications, workshops and other outreach 
activities, and expressed first and foremost as directed towards Sami stakeholders, Sami groups and Sami society as a whole:

"Sámi cultural associations and the National Association of Swedish Sámi (SSR ) play a significant role for communication of results with stakeholders. Dissemination of results will be carried out along the research process via a project webpage and through popular science presentations with Sámi associations."

Research dissemination is also frequently directed towards the academic society by means of scientific conferences and publishing the results in scientific journals aimed at an academic public:

"For the dissemination it is important that the results are presented at relevant conferences and the budget include eight papers at five different conferences, two national and three international."

In the sections of the applications that highlight the issue of dissemination, a distinction is generally made between communicating results to "the scientific community" on one hand, and "the Sami community" on the other. Indeed, dissemination of the new knowledge generated is to be transferred either to the scientific or the Sami community - not, it would seem, the two together. The risk is thereby similar to what Adams and Faulkhead have highlighted, that this separation "reinforces division between community processes and academic methodologies, methods, ethics, permissions and ways of representing and presenting results" (Adams and Faulkhead 2012, p. 1016). This division in turn risks the possibility that academically produced knowledge loses legitimacy amongst the particular indigenous community that is in focus (Ledman [Drugge] 2015).

\section{Informed Consent}

As illustrated in Table 1, the source material confirms that some researchers refer to general ethical principles or national legislation when discussing ethical issues. It should be noted that these guidelines in themselves include sections focusing on basic principles concerning informed consent, anonymity and voluntary participation. Thus, referring for instance to the CODEX (rules and guidelines for research) of the VR entails an assumption that certain ethical principles will be followed. In addition to references to the ethical principles inherent in the guidelines mentioned, informed consent is explicitly described as important in $39 \%$ of all the studied research submissions, albeit usually without any in-depth discussion. The following is a typical example:

"Ethical consent will be obtained prior to the start of the project, according to Swedish legislation (Act concerning the Ethical Review of Research Involving Humans, 2003:460)."

Focusing on informed consent as an important ethical issue can be related to general discussions within the academic context, and be seen as an attempt to avoid repeating past atrocities which is not too strong a word - in research practices (for instance, the case of Tuskagee). Furthermore, informed consent often dominates the ethical review process (Johnsson et al. 2014, p. 38; Eriksson et al. 2008, p. 15). Added to this and seen from a post-colonial perspective, research in Sweden related to the Sami people has a history of seeking to prove that the Sami are inferior to the Swedes. Race biology research in the 1900s supported far-reaching political decisions, leading to negative consequences that still affect many families in Sami society today (Drugge 2016a; Svalastog 2013). In light of this deeply troubled historical backdrop, prioritizing informed consent may be regarded as an important way to prevent future abuse in the name of research. 


\section{Anonymity}

In order to protect individual subjects within studied groups, confidentiality through anonymity is often promised by researchers (Svalastog and Eriksson 2010, p. 104). In most cases, groups studied consist of a large number of people in which the individual is easily hidden. However, in the context of a sub-group identification is sometimes possible even though details are changed (Svalastog and Eriksson 2010, p. 106). Within the field of indigenous research, the issue of anonymity has been highlighted as problematic for several reasons. Anonymity is discussed from a different angle to the academic norm, challenging the default position by suggesting that it risks obscuring indigenous agency and knowledge. Scholars such as Peter Kulchyski highlight the importance of naming in order to prevent homogenization of an indigenous group and avoid mystifying; the individual and his or her specific knowledge should be acknowledged (Kulchyski 2005, p. 19). Similarly, Eriksson and Svalastog argue that "anonymity risks making research distressingly similar to stealing", particularly when research relates to "resources, knowledge, property and traditions". Instead, the "default" anonymity is contested and careful adjustment to the specific theme, questions and context of each research project is recommended (Svalastog and Eriksson 2010, p. 110). The decision to safeguard or neglect anonymity is in fact in itself an issue of ethical character that needs to be discussed in each specific context (Scarth 2015, p. 7).

Discussions about anonymity occur in $29 \%$ of the submissions considered here; they tend to depart from three separate standpoints. On one hand, anonymity is included as an integral part of the references to Codices, legislative Acts or general ethical guidelines. In that context, the issue of anonymity is presumed as a way to protect the integrity of the research participants, and is highlighted as something which is straightforward and unproblematic:

"In all steps, the integrity and anonymity of the informants will be guaranteed."

A second way of discussing anonymity is by explaining it as an open issue that is left to the participants themselves to decide; this enables them to consider what has traditionally been seen as an important issue in academia from a variety of alternative angles. Sometimes, and in the face of conventional thought, a lack of anonymity may not be seen as a problem, as in the following example:

"I have, in agreement with my interviewees, decided that the interviewees will be presented with full name and position. The normal procedure for qualitative research is to anonymize the interviews. Neither the interviewees nor me would like that."

Thirdly, anonymity is discussed in direct relation to the indigenous context, acknowledging that the Sami community is small, which makes it difficult to guarantee anonymity:

"Indigenous communities are commonly small, and maintaining anonymity may well involve more than simply using fictitious names."

\section{Conclusions}

The results of this study confirm that a full ten years on from the Formas report into Sami research there is still widespread uncertainty among scholars over whether discussions of ethics are relevant in the first place, what they are supposed to include, how they are meant to be undertaken and what consequences can be expected from the presence or absence of ethics in indigenous research. 
Internationally, guidelines for ethical indigenous research are now abundant and easily accessible. However, guidelines developed for other indigenous contexts are not automatically transferrable to a Swedish academic setting. Although they can serve very well as inspiration or encourage reflection, they do need to be tailored to the specific research context in Sweden and/or Sápmi. In the elaboration of guidelines for indigenous research it has been repeatedly underscored how crucial it is that the development process is initiated and led by indigenous representatives; only then do such studies gain legitimacy within the indigenous community (Battiste and Youngblood Henderson 2000; Weijer et al. 1999). Up until now, such Samicentric initiatives have been notably absent in Sweden, which has created a situation where researchers are unable to move ethical processes forward if they are not identified as indigenous. On the other hand, indigenous scholars risk being considered ethical just by virtue of being indigenous, rather then by acting in line with culturally and ethically appropriate research methods. Consequently, and as demonstrated in this study, the collective scientific body engaged in Sami research in Sweden lack maps and tools that would enable them to progress in their efforts to be ethical, even though many would agree that existing ethical regulations are both insufficient and inadequate when seen from a Sami perspective.

Highlighting the importance of ethics in indigenous research is a responsibility that should undoubtedly concern Swedish legislators and research institutions. In addition, I would argue that the onus to accomplish a change needs to be shared with the official representatives of the Sami people in Sweden, the Sami Parliament and other key Sami organizations. To criticize how research processes, designs, methods and questions are formulated is an easy thing to do from a Sami perspective, but the initiative and drive to seek improvement by taking control and defining ethically appropriate standards appears to be lacking: the result is a catch-22 situation that must be broken if scholarship is to progress and improve.

This article should not be interpreted as a critique of individual researchers, research environments or groups within the field of Sami research. Instead, it demonstrates that many scholars within indigenous research are all too aware of the ethical complexities that can arise and are eager to "do things right" from an ethical perspective, but they are lacking sufficient support in order to be able to do so. Working in this void, scholars are likely to grab indiscriminately for the nearest ethical guidance available, leading to substantial differences in individual researchers' strategies. Deciding what the process of "doing things right" involves is currently left up to the isolated scholar to determine, inevitably nourishing a range of different approaches and strategies that could be eminently suitable or, in the worst case scenario, completely inappropriate. To remedy this unsatisfactory situation, discussions need to take place at different levels both within and outside academia. Developing ethical guidelines that are specifically tailored for Sami research would reduce the anxiety of the individual scholar while also ensuring that research is transformed from being an issue merely of academic concern to something that is based in, and is of greater tangible benefit to, the Sami community as a whole.

\section{Compliance with Ethical Standards}

Conflict of Interest I declare that I have no conflict of interest.

Open Access This article is distributed under the terms of the Creative Commons Attribution 4.0 International License (http:/creativecommons.org/licenses/by/4.0/), which permits unrestricted use, distribution, and reproduction in any medium, provided you give appropriate credit to the original author(s) and the source, provide a link to the Creative Commons license, and indicate if changes were made. 


\section{References}

Adams, K., \& Faulkhead, S. (2012). "This Is Not a Guide to Indigenous Research Partnerships" in Information. Communications Society, 15(7), 1016-1036. doi:10.1080/1369118X.2012.709260.

Alfred, T., \& Corntassel, J. (2005). Being Indigenous: Resurgences against Contemporary Colonialism. Government and Opposition, 40(4), 597-614. doi:10.1111/j.1477-7053.2005.00166.x.

Axelsson, P \& Sköld, P. (2006). Samisk forskning - eftersatt och efterfrågad. Tvärsnitt: Humanistisk och samhällsvetenskaplig forskning 1: 18-22.

Battiste, M, \& Youngblood Henderson, J. (2000). Protecting Indigenous Knowledge and Heritage: A Global Challenge. Purich's Aboriginal Issues Series. Saskatoon: Purich Publ.

Bockgård, G., \& Tunón, H. (2010). Gäller vanligt folkvett också för akademiker? Rapport från ett seminarium om makt och etik. Uppsala: Naptek.

Brännlund, I. (2015). Histories of Reindeer Husbandry Resilience : Land Use and Social Networks of Reindeer Husbandry in Swedish Sápmi 1740-1920. Umeå: Vaartoe-Centre for Sami Research.

Chilisa, B. (2011). Indigenous Research Methodologies. London: SAGE.

CIHR (2012). The Canadian Institutes of Health Research. Integrated and End-of-Grant Approaches: Guide to Knowledge Translation Planning at CIHR.

Denzin, N., \& Lincoln, Y. (2005). The Sage Handbook of Qualitative Research (3. ed.). Thousand Oaks, California: Sage.

Drugge, A-L. (2016a). "Forskningsetik och urfolksforskning”. In D. Lindmark \& O. Sundström (Eds.), De historiska relationerna mellan Svenska kyrkan och samerna: En vetenskaplig antologi. Skellefteå: Artos \& Norma.

Drugge, A-L (Ed.) (2016b). Ethics in indigenous research. Past experiences - future challenges. Umeå: Vaartoe - Centre for Sami Research.

Eriksson, S., Höglund, A., \& Helgesson, G. (2008). Do Ethical Guidelines Give Guidance? A Critical Examination of Eight Ethics Regulations. Cambridge Quarterly of Healthcare Ethics: CQ: The International Journal of Healthcare Ethics Committees, 17(1), 15-29. doi:10.1017/S0963180108080031.

Etikprövning av forskning, Prop 2002/03:50 [Ethical vetting in research, Government Bill]

Ett lyft för forskning och innovation, Proposition 2008/09:50 [An improvement for research and innovation. Government Bill]

GERAIS (2012). Guidelines for Ethical Research in Australian Indigenous Studies. Australian Institute for Aboriginal and Torres Strait Islander Studies (AIATSIS)

Hagerman, M. \& Gabrielson, C. (2014). Hur gör man för att rädda ett folk? [How to save a people?] http:// majahagerman.se/hur-gor-man-for-att-radda-ett-folk-om-herman-lundborg-chef-for-rasbiologiska-institutet/

Hållbar rennäring och övrig samerelaterad forskning: Kunskapsöversikt. (2006). Rapport (Formas), 1653-3003; 2006:3. [Sustainable reindeer herding industry and other Sami related research] Stockholm: Formas. http:// www.formas.se/upload/EPiStorePDF/Hallbar rennaring R3 2006/Halllbar rennaring.pdf.

Hassler, S. (2005). The Health Condition in the Sami Population of Sweden, 1961-2002: Causes of Death and Incidences of Cancer and Cardiovascular Diseases. Umeå: Department of Public Health and Clinical Medicine, Umeå University.

Hsieh, H.-F., \& Shannon, S. (2005). “Three Approaches to Qualitative Content Analysis". Qualitative Health Research, 15(9) SAGE.

Hudson, M., Milne, M., Reynolds, P., Russell, K., \& Smith, B. (2010). Te Ara Tika: Guidelines for Māori Research Ethics: A Framework for Researchers and Ethics Committee Members.

Hunter, D. (2014). "Can research ethics committees stop unethical international trials? in Research Ethics, no 10:66. SAGE. doi:10.1177/1747016114542213.

Johnsson, L., Eriksson, S., Helgesson, G., \& Hansson, M. (2014). Making Researchers Moral: Why Trustworthiness Requires More than Ethics Guidelines and Review. Research Ethics, 10(1), 29-46. doi: 10.1177/1747016113504778.

Jonsson, Å. (2010. Árbbediehto/Aerpimaahtoe: Sametingets Policydokument För Traditionell Kunskap. Sametinget.

Kalman, H., \& Lövgren, V. (2012). Etiska dilemman : forskningsdeltagande, samtycke och utsatthet. Malmö: Gleerups.

Kulchyski, P. (2005). Like the sound of a drum. Aboriginal cultural politics in Denendeh and Nunavut. Winnipeg: University of Manitoba Press.

Lag om etikprövning av forskning som avser människor 2003:460 [Ethical review Act].

Lantto, P. (2000). Tiden börjar på nytt: En analys av samernas etnopolitiska mobilisering $i$ Sverige 1900-1950. Kulturens Frontlinjer 32. Umeå: Institutionen för nordiska språk, Umeå Universitet.

Ledman [Drugge], A-L. (2007). "Etik och reflexivitet i samisk forskning". In Å. Bergenheim (Ed.), Forska rätt: texter om etik och historisk forskning. Umeå: Department of Historical studies.

Ledman [Drugge], A-L. (2012a). Att representera och representeras: Samiska kvinnor i svensk och samisk press 1966-2006 [To represent and be represented: Sami women in Swedish and Sami Press, 1966-2006]. Umeå: Department of Historical, Philosophical and Religious studies. 
Ledman [Drugge], A-L. (2012b). “Att utmana koloniala strukturer: etik i samiskrelaterad forskning” in Bårjås. Drag: Árran lulesamisk senter.

Ledman [Drugge], A-L. (2015). "Turning the gaze from 'Them' to 'Us'. Challenging the mainstream in indigenous research”. In P. Sköld, M. Sandström \& M. Bolaane (Eds.), Under the same sun: parallel issues and mutual challenges for San and Sami peoples and research. Umeå: Vaartoe - Centre for Sami Research.

Lindmark, D., \& Sundström, O. (Eds.) (2016). De historiska relationerna mellan svenska kyrkan och samerna [The historical relations between the Swedish church and the Sami]. Skellefteå: Artos och Norma bokförlag.

Lundmark, L. (1998). Så länge vi har marker: Samerna och staten under sexhundra år. Stockholm: Rabén Prisma.

Milmaniene, P. (2009). Hacia Una Ética de La Investigación Orientada a La Protección de Las Comunidades Y Los Grupos Étnicos. Anuario de Investigaciones, 16(December), 249-256.

Mörkenstam, U. (1999). Om "Lapparnes privilegier": Föreställningar om samiskhet i svensk samepolitik 18831997. Stockholm Studies in Politics: Stockholm University.

NESH Den nasjonale forskningsetiske komité for samfunnsvitenskap og humaniora (2002) Samisk forskning og forskningsetikk [Sami research and research ethics].

Personuppgiftslagen 1998:204 [Personal Data Act] 1998:20.

Pikkarainen, H. (2008). Discrimination of the Sami: the rights of the Sami from a discrimination perspective. Stockholm: The Equality Ombudsman.

Rydenfalk, David. (2014) "Sáminuorra sex år före Sametinget" [Sáminuorra six years ahead of the Sami Parliament. Sameradion \& SVT Sápmi, May 26, 2014. http://sverigesradio.se/sida/artikel.aspx? programid $=2327 \&$ artikel $=5872467$

Sametinget [The Sami Parliament]. 2016. "En samisk sanningskommission" [A Sami truth- and reconciliation commission]. https://www.sametinget.se/sanningskommission.

Sametinget [The Sami Parliament]. 2015. "DO och Sametinget verkar för en samisk sanningskommission" [The Equality Ombudsman and the Sami Parliament are striving for a Sami truth- and reconciliation commission]. https://www.sametinget.se/90491.

Scarth, B. (2015). "Bereaved participants' reasons for wanting their real names used in thanatology research". Research Ethics, 12(2) SAGE. doi:10.1177/1747016115599569.

Schinke, R. J., Enosse, L., Peltier, D., Watson, J., \& Lightfoot, N. (2010). Cultural missteps and ethical considerations with indigenous populations: preliminary reflections from northeastern Ontario, Canada. Journal of Academic Ethics, 8(4), 233-242. doi:10.1007/s10805-010-9125-9.

Sehlin Macneil, K. (2014). Vad är urfolksmetodologier? Kulturella Perspektiv, 23(1), 50-57.

Smith, L. (1999). Decolonizing methodologies: research and indigenous peoples. London: Zed.

"Support studies of the indigenous Sami people, Sámi-related activities, health, working and living conditions" (2012), research proposals $(n=56)$ submitted to and available at the research council Formas.

Svalastog, A. (2013). Making it transparent. On naming, framing and administrating biobank research on native people. New Genetics and Society, 32(3), 209-242. doi:10.1080/14636778.2012.760265.

Svalastog, A., \& Eriksson, S. (2010). "You can use my name; you don't have to steal my story - a critique of anonymity in indigenous studies". Developing World Bioethics, 10(2). doi:10.1111/j.1471-8847.2010.00276.x.

The Belmont Report. (1979) Ethical Principles and Guidelines for the Protection of Human Subjects of Research." Departmend of Health, Education and Welfare. http:/www.hhs.gov/ohrp/humansubjects/ guidance/belmont.html.

The Declaration of Helsinki. (1964) Ethical Principles for Medical Research Involving Human Subjects." World Medical Association. http://www.wma.net/en/30publications/10policies/b3/index.html.pdf?print-mediatype \&footer-right=[page]/[toPage].

The Equality Ombudsman. (2013). Project LED 2013/156, "Discrimination of the Sami as Indigenous Peoples".

The Nürnberg codex. (1949). Trials of War Criminals Before Nuernberg Military Tribunals, under Control Counsel Law No. 10, Nuernberg, Oct. 1946-Apr. 1949. Vol. 2: Case I, United States vs. Karl Brandt, et Al. (the Medical Case). 1950. Vol. 142.

Tri-Council Policy Statement: Ethical Conduct for Research Involving Humans. 2010. Canadian Insitutes of Health Research, Natural Sciences and Engineering Research Council of Canada, and Social Sciences and Humanities Research Council of Canada. http://www.pre.ethics.gc.ca/pdf/eng/tcps2/ TCPS_2 FINAL_Web.pdf.

Weijer, C., Goldsand, G., \& Emanuel, E. J. (1999). Protecting communities in research: current guidelines and limits of extrapolation. Nature Genetics, 23(3), 275-280. doi:10.1038/15455.

Nygren, L. (2012). "Risken finns, finns nyttan?: Etikprövningsnämnderna och den kvalitativa forskningen. 